ORIGINAL ARTICLE

\title{
Identifying the Supply Chain Risk Factors in Cinnamon Export Industry in Sri Lanka
}

P.T.R.S. Sugathadasa ${ }^{1}$, H.N. Perera ${ }^{1,2, *}$, H.C. Hewage ${ }^{1}$ and S.P.A.V.S. Samarakoon ${ }^{1}$

\section{${ }^{1}$ Department Transport \& Logistics Management, Faculty \\ of Engineering, University of Moratuwa, Katubedda 10400, Sri Lanka. \\ ${ }^{2}$ Professor H.Y. Ranjit Perera Institute for Applied Research, Nugegoda 10250, Sri Lanka.}

\section{Correspondence:}

*hniles@uom.lk

(D) https://orcid.org/0000-0001-6329-5967

DOI: http://doi.org/10.4038/sljae.v3i1.62

\begin{abstract}
Although Sri Lanka is one of the leading exporters of cinnamon in the world, the growth of the cinnamon industry is slow due to supply chain risk factors. Thus, the cinnamon supply network connecting the producers and the export market has not been properly optimized and results in inefficiencies. The purpose of this research was to examine the supply chain risk factors in the cinnamon export industry in Sri Lanka, by analyzing them to identify critical risk factors, and formulate the risk mitigation strategies to overcome their adverse impacts. An extensive review of literature, and unstructured interviews with industry personnel were conducted to identify the risk factors. Then, a questionnaire was distributed among the industry personnel to rank the identified risk factors based on a Likert type scale. Risk matrix analysis was employed to assess the risk factors. Five critical risk factors were identified related to quality control, communication, timing of product delivery, inventory, and lack of technology which demands immediate mitigation strategies. The key areas of the mitigation strategies are technological enhancements, research and development, and initiatives to make awareness on industry best practices.
\end{abstract}

Keywords: Cinnamon, Supply Chain Risk Factors, Risk Matrix, Risk Mitigation strategies 


\section{Introduction}

From historic eras, Sri Lanka is well known around the world for its spices such as cinnamon, cardamom, pepper, nutmeg, and clove. This industry is one of the salient contributors to the national economy. The study is focused on Cinnamon Supply Chain (CSC), one of the oldest and significant spices grown in Sri Lanka. Sri Lankan cinnamon, "Pure Ceylon Cinnamon" has its own reputation globally because of its unique colour, flavour, and aroma (Hettiarachchi et al. 2020). In 2018, Sri Lankan cinnamon exports represent $41.13 \%$ of the world's total export of cinnamon (EDB, 2018). Furthermore, the Export Development Board (EDB) highlights that cinnamon related products account for $54 \%$ of the quantity of total export of spices.

Sri Lanka exports cinnamon in primary form, crushed form, and powder form. Cinnamon is widely used for beverages and bakery products, pharmaceutical and cosmetics products. Nearly 93,767 families are directly engaged in the cinnamon industry (Bawappa et al. 2005). Galle district (41\% from total cultivation) accounts for the highest cinnamon cultivation in Sri Lanka followed by Matara (21\%) and Ratnapura (14\%). Other producing districts are Badulla, Hambantota and Kalutara (DEA, 2014, 2017).

Key strengths of Sri Lanka's cinnamon industry are; uniqueness and the quality of the product, appropriate geographical location, favourable climate conditions, and availability of the labour. Major challenges of the industry are limited transportation and warehouse facilities, Research and Development (R\&D) support, and institutional support to smallholder producers (Hettiarachchi et al. 2020; Sugathadasa et al. 2021; UNIDO, 2016a; Yoon et al. 2020). Silva (2014) highlighted that once these challenges are successfully tackled, cinnamon production can easily be doubled.

In our study, we considered exporters as the focal point of CSC. Thus, primary players of the upstream of the CSC are input suppliers (e.g., raw material, equipment, and machinery, etc.), producers (e.g., growers, cinnamon peelers, factories, etc.). collectors (i.e., traders), balers and value-added 
producers (Hettiarachchi et al. 2020; Yoon et al. 2020). The key activities of the upstream are supplying raw material, production, collecting, trading, and value-adding. Furthermore, the main supporting activities are supplying equipment and machinery, planting materials, field demonstrations, subsidies, training, and advisory services (Hettiarachchi et al. 2020; UNIDO, 2016a). Downstream of the CSC mainly comprises exporters, and buyers. Exporters acts as the link between buyers and the traders. Thus, the key activities of the downstream are exporting and consumption (Hettiarachchi et al. 2020; Yoon et al. 2020).

The CSC often faces a vast range of inherent risks that can be occurred instantaneously to interrupt the performance of the entire chain. Ho et al. (2015) define the supply chain risk as "the likelihood and impact of unexpected macro and/or micro-level events or conditions that adversely influence any part of a supply chain leading to operational, tactical, or strategic level failures or irregularities". Thus, the supply chain risk can be identified as the future uncertainty about deviation from uncertainty of expected income. It includes strategic, financial, and operation failures, market disruptions, environmental disasters, and regularity violations (Sugathadasa \& Perera, 2021).

Past literature exposes five basics risk categories namely financial, legal, environmental, sociopolitical and human behaviour risks (Perera et al. 2020; Sugathadasa \& Rajapaksha, 2011; Thanthirige, 2011). However, CSC has a lot of associated risks and some of the risks are unique to the industry. One such example is that the $70 \%$ of the producers are smallholders and cultivate as part time growers (DEA, 2014; Hettiarachchi et al. 2020; Yoon et al. 2020).

Furthermore, price volatility, unavailability of quality plant materials, high labour cost, and limited awareness on quality standards can be identified as the key risks from farmers' point of view. On the other hand, collectors face transportation, warehousing, quality assurance, value addition and freight forwarding risks in the CSC 
(Hirimuthugodage, 2016; S. Perera et al. 2017; Thanthirige, 2011).

In order to have an efficient CSC, we should focus on monitoring and evaluating supply chain risks and ways of mitigation. Past literature highlights two key risks mitigation approaches, as reactive and proactive (Ho et al. 2015; Sugathadasa et al. 2021). The reactive approach is the implementation of mitigation strategies after the occurrence of risk event whereas proactive approach acts before the occurrence of the risk event (Qazi \& Akhtar, 2020; Sugathadasa et al. 2020). Some of the suggested risks mitigation strategies are collaboration of the smallholders, consolidation strategies for transportation, and seamless information flow through technological enhancements (Balachandra et al. 2020; UNIDO, 2016b).

The export market is the key market segment in the cinnamon industry in Sri Lanka since it accounts for $54 \%$ of the volume of total spices exported (EDB, 2018). However, the growth of the cinnamon industry is slow due to supply chain risk factors. Only a few studies have been focused on identifying risks factors in the CSC in the Sri Lankan context. Thus, the main objective of our study was to identify the risk factors in the
CSC. For determining the impact of the risk factors, a quantitative analysis was conducted. The key contribution of this study is identifying the critical supply chain risk factors in the CSS and to provide mitigation strategies to overcome the adverse impact of those risk factors.

\section{Materials and Method}

\section{Research Design}

\section{Background study}

Literature Survey (Journals and E Resources) and Unstructured interviews

Identify the supply Chain Risk factors and map the process

Questionnaire Design

Data Collection

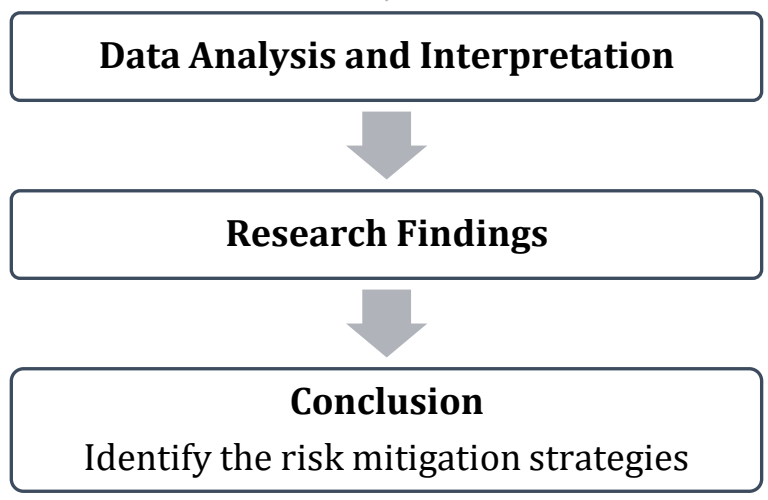

Figure 1. Research Process 
The research design comprises of two stages. First, an extensive study of literature and unstructured interviews were conducted with industry-related personnel to identify risk factors and potential mitigation strategies in CSC. Second, a survey was conducted using a questionnaire developed including the information gathered from the first stage. Fig. 1 depicts the research process of the study.

\section{Data Collection}

Unstructured interviews in the first and second steps were carried out with 15 producers, 10 collectors and 5 exporters in the CSC to identify the supply chain structure and risk factors of cinnamon industry (Fig. 1). Furthermore, an extensive literature survey was conducted to identify the risk categories (Hirimuthugodage, 2016; Sugathadasa et al. 2020; Thanthirige, 2011; UNIDO, 2016a, 2016b; Yoon et al. 2020). Table 1 shows the 19 potential risk factors identified under 6 categories according to the literature and expert interviews.

In the third and fourth steps involved questionnaire development and survey data collection. The questionnaire (see Annexure) consisted of two main sections;

- Section 1 - General information about the organization

- Section 2 - Ranking (Table 2) the major supply chain risk factors in the industry (i.e., probabilities and severity of the identified risk factors). Probability of risk factors and their severity were measured based on a Likert type scale ranging from very low (1) to very high (5).

Registered cinnamon exporters in Sri Lanka Export Development Board (SLEDB) have selected for the survey. Then the questionnaire was emailed to the managerial level employees of the 52 registered cinnamon exporters in Sri Lanka. However, only 27 responses were received from participants due to time constraints. Thus, the response rate of the survey was $51.92 \%$ from the total population (52 registered exporters). 
Table 1. Categorization of risk types

\begin{tabular}{|c|c|c|c|}
\hline \multirow{2}{*}{ Risk Category } & \multirow{2}{*}{ Risk Factor } & \multicolumn{2}{|r|}{ Source } \\
\hline & & Interviews ${ }^{1}$ & Reference \\
\hline \multirow{4}{*}{$\begin{array}{l}\text { Logistical and } \\
\text { infrastructural } \\
\text { risk }\end{array}$} & Risk of inventory & Yes & $\begin{array}{l}\text { Hettiarachchi et al. (2020); Hirimuthugodage (2016); } \\
\text { Thibbotuwawa et al. 2017; UNIDO, 2016a; Yoon et al. } \\
\text { 2020) }\end{array}$ \\
\hline & Risk of transport & Yes & $\begin{array}{l}\text { Hirimuthugodage (2016); UNIDO (2016a); } \\
\text { Thibbotuwawa et al. (2017); Yoon et al. (2020) }\end{array}$ \\
\hline & $\begin{array}{l}\text { Risk of freight } \\
\text { forwarding }\end{array}$ & Yes & NA \\
\hline & $\begin{array}{l}\text { Communication } \\
\text { risk }\end{array}$ & Yes & Thanthirige (2011); Yoon et al. (2020) \\
\hline \multirow{3}{*}{$\begin{array}{l}\text { Market-related } \\
\text { risk }\end{array}$} & $\begin{array}{l}\text { Changes related to } \\
\text { the market \& } \\
\text { demand }\end{array}$ & Yes & $\begin{array}{l}\text { Thanthirige (2011); UNIDO (2016b); Thibbotuwawa } \\
\text { et al. (2017); Yoon et al. (2020) }\end{array}$ \\
\hline & $\begin{array}{l}\text { Impact of domestic } \\
\text { \& international } \\
\text { prices }\end{array}$ & Yes & $\begin{array}{l}\text { Hettiarachchi et al. (2020); UNIDO (2016a); } \\
\text { Thibbotuwawa et al. (2017); Yoon et al. (2020) }\end{array}$ \\
\hline & $\begin{array}{l}\text { Timing of product } \\
\text { delivery }\end{array}$ & Yes & $\begin{array}{l}\text { Hettiarachchi et al. (2020); Hirimuthugodage, (2016); } \\
\text { UNIDO (2016a); Yoon et al. (2020) }\end{array}$ \\
\hline \multirow{4}{*}{$\begin{array}{l}\text { Management } \\
\text { and } \\
\text { operational } \\
\text { risk }\end{array}$} & $\begin{array}{l}\text { Management } \\
\text { decision making }\end{array}$ & Yes & NA \\
\hline & Quality control & Yes & $\begin{array}{l}\text { Hirimuthugodage, (2016); UNIDO, (2016b); } \\
\text { Thibbotuwawa et al. (2017); Yoon et al. (2020) }\end{array}$ \\
\hline & $\begin{array}{l}\text { Changes in labor } \\
\text { force }\end{array}$ & Yes & $\begin{array}{l}\text { Hettiarachchi et al. (2020); Sugathadasa et al. (2021); } \\
\text { UNIDO (2016a); Yoon et al. (2020) }\end{array}$ \\
\hline & Lack of technology & No & $\begin{array}{l}\text { Bawappa et al. (2005); Thanthirige (2011); } \\
\text { Thibbotuwawa et al. (2017); Yoon et al. (2020) }\end{array}$ \\
\hline \multirow{4}{*}{$\begin{array}{l}\text { Public policy } \\
\text { and } \\
\text { institutional } \\
\text { risk }\end{array}$} & $\begin{array}{l}\text { Financial and tax } \\
\text { policies }\end{array}$ & Yes & Hettiarachchi et al. (2020); Yoon et al. (2020) \\
\hline & $\begin{array}{l}\text { Regulatory and } \\
\text { legal policies }\end{array}$ & No & $\begin{array}{l}\text { Hettiarachchi et al. (2020); UNIDO (2016b); } \\
\text { Thibbotuwawa et al. (2017); Yoon et al. (2020) }\end{array}$ \\
\hline & $\begin{array}{l}\text { Trade \& market } \\
\text { policies }\end{array}$ & No & $\begin{array}{l}\text { Hettiarachchi et al. (2020); UNIDO (2016b); } \\
\text { Thibbotuwawa et al. (2017); Yoon et al. (2020) }\end{array}$ \\
\hline & $\begin{array}{l}\text { Weak institutional } \\
\text { capacity }\end{array}$ & Yes & $\begin{array}{l}\text { Hettiarachchi et al. (2020); UNIDO (2016b); Yoon et } \\
\text { al. (2020) }\end{array}$ \\
\hline \multirow{2}{*}{ Political risk } & $\begin{array}{l}\text { The political } \\
\text { environment of the } \\
\text { country }\end{array}$ & No & $\begin{array}{l}\text { Hettiarachchi et al. (2020); Sugathadasa et al. (2020); } \\
\text { UNIDO (2016a); Yoon et al. (2020) }\end{array}$ \\
\hline & $\begin{array}{l}\text { Interruption of } \\
\text { trade due to } \\
\text { dispute }\end{array}$ & No & $\begin{array}{l}\text { Hettiarachchi et al. (2020); UNIDO (2016a); Yoon et } \\
\text { al. (2020) }\end{array}$ \\
\hline \multirow{2}{*}{$\begin{array}{l}\text { Risk related to } \\
\text { nature }\end{array}$} & Natural disasters & Yes & NA \\
\hline & $\begin{array}{l}\text { Biological \& } \\
\text { environmental risk }\end{array}$ & Yes & (Hirimuthugodage, 2016; Yoon et al. 2020) \\
\hline
\end{tabular}

\footnotetext{
${ }^{1}$ Unstructured interviews were carried out with 15 producers, 10 collectors and 5 exporters in the CSC
} 


\section{Data Analysis}

As identified in Fig. 1, the fifth step in the process is data analysis. The Risk Matrix method was employed to conduct the risk analysis in this study. Probability of the occurrence and the severity of a risk event are the two constructs considered in Risk Matrix (Ho et al. 2015; Qazi \& Akhtar, 2020; Ratnayake \& Antosz, 2017). The process of creating the Risk Matrix consisted of three steps as explained below.

Step 1 - Scaling the probability and severity of a risk event (i.e., a risk factor) measures on the five-point Likert Scale;

(1) - Very Low, (2) - Low, (3) Moderate, (4) - High, and (5) - Very High

Step 2 - Identify the output of Scale Index

The scale index table (Table 2) is referred to prepare the risk index of a risk based on

the probability and the impact. Magnitude of a risk factor " $R$ " is identified using the equation 1 (Ho et al.
2015; Qazi \& Akhtar, 2020; Ratnayake \& Antosz, 2017).

$\mathrm{R}=\mathrm{P} \times \mathrm{S}$

Where, $\mathrm{R}=$ Magnitude of the Risk, $\mathrm{P}=$ Probability of the event and $S=$ Severity of the event

Step 3 - Prepare the Standard Risk Matrix

The probability of occurrence and severity of an event is divided into five levels as 1-5 and map in the Risk Matrix (Ho et al. 2015; Qazi \& Akhtar, 2020; Ratnayake \& Antosz, 2017). Magnitude of the risk matrix (Table 3 ) is prepared using Equation 1 based on the scale of probability and the scale of severity. 
Table 2. Scale Index table

\begin{tabular}{|l|c|c|l|c|c|}
\hline \multicolumn{3}{|c|}{ Probability (P) } & \multicolumn{3}{c|}{ Severity (S) } \\
\hline Likert Scale & Index & Numerical Scale & Likert Scale & Index & Numerical Scale \\
\hline Very Low & P1 & 1 & Very Low & S1 & 1 \\
\hline Low & P2 & 2 & Low & S2 & 2 \\
\hline Moderate & P3 & 3 & Moderate & S3 & 3 \\
\hline High & P4 & 4 & High & S4 & 4 \\
\hline Very High & P5 & 5 & Very High & S5 & 5 \\
\hline
\end{tabular}

Table 3. Magnitude of the Risk Matrix

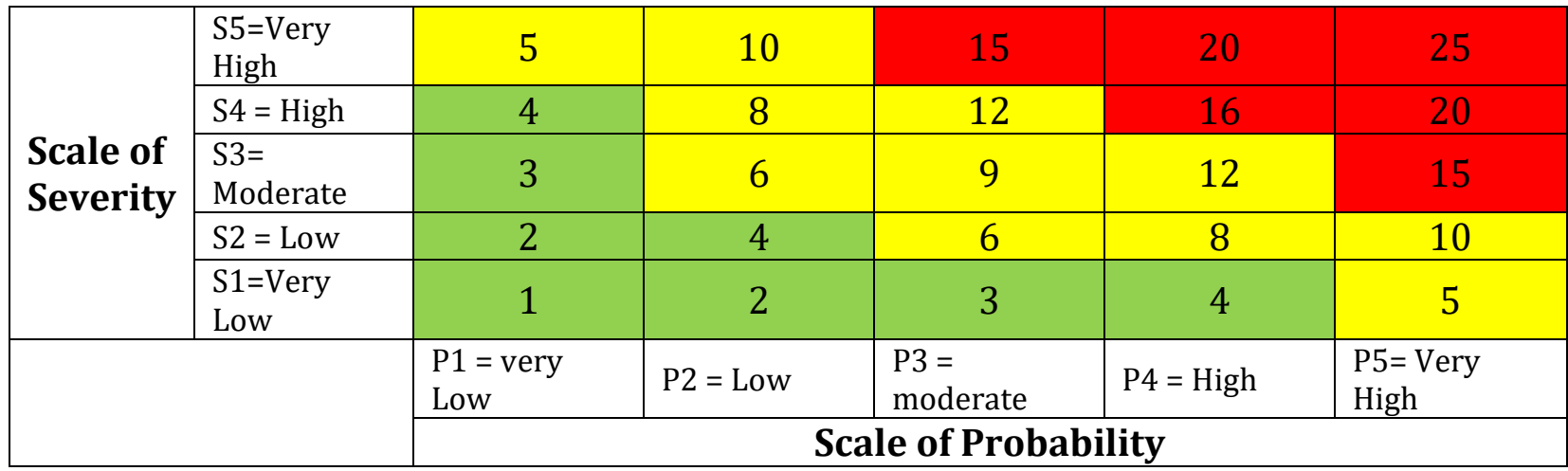

The magnitude of a risk is categorized into three categories; 1 - 4 Negligible, 5 12 Moderate and 15 - 25 critical.

Table 4. Risk Matrix Index

\begin{tabular}{|c|c|c|}
\hline Colour & Index & Category \\
\hline & $\mathrm{N}$ & Negligible \\
\hline & $\mathrm{M}$ & Moderate \\
\hline & $\mathrm{C}$ & Critical \\
\hline
\end{tabular}

Finally, collective risk factor index was developed by assessing the risk matrix for each factor based on the responses we collected through the questionnaire. The mean of the response risk is calculated using equation 3 to develop the Grid of Risk Matrix (Ho et al. 2015; Qazi \& Akhtar, 2020; Ratnayake \& Antosz, 2017).

Mean of the response risk $=\frac{\varepsilon_{i}^{n} R_{i j}}{n}$ (Eq. 3)

Where, $R i j=$ magnitude of risk of responder $i$ for $j$ risk type and $n=$ number of responses. 
Table 5. Grid of Risk Matrix

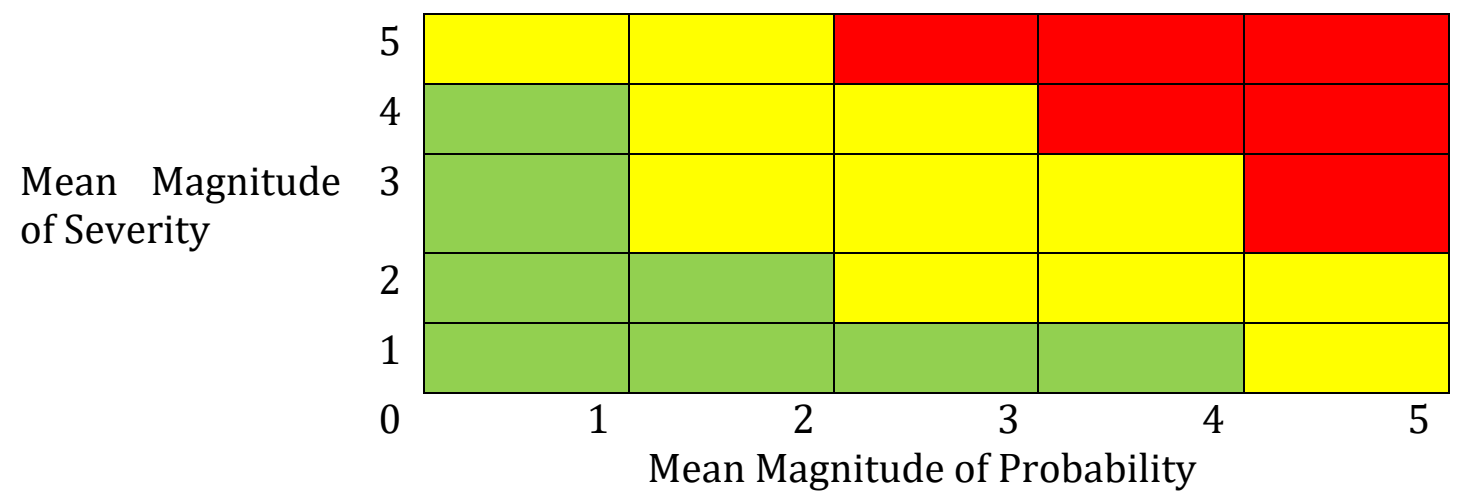

According to the magnitude of the risk, risk category is selected as depicted in Table 5. This shows that the higher the mean value of the severity and the probability of the occurrence, the higher the risk.

\section{Results and discussion}

\section{Supply Chain Structure of Cinnamon Industry in Sri Lanka}

Three key actors of the cinnamon industry mainly growers, collectors, and exporters were considered for the study based on

the initial interviews. Fig. 2 shows the structure of the CSC in Sri Lanka. Growers purchased cinnamon saplings from private nurseries and Department of Export Agriculture.
They used both organic and chemical fertilizers to their cultivation. However, the use of pesticide and weedicides is lower for cinnamon compared to other agricultural crops (Thibbotuwawa et al. 2017). Some of the major issues confronted by the producers are high cost of fertilizer, labour cost $(67 \%$ of production cost), unskilled labour, limitation of suitable land for cultivation and lack of appropriate technology for peeling (Thibbotuwawa et al. 2017). 


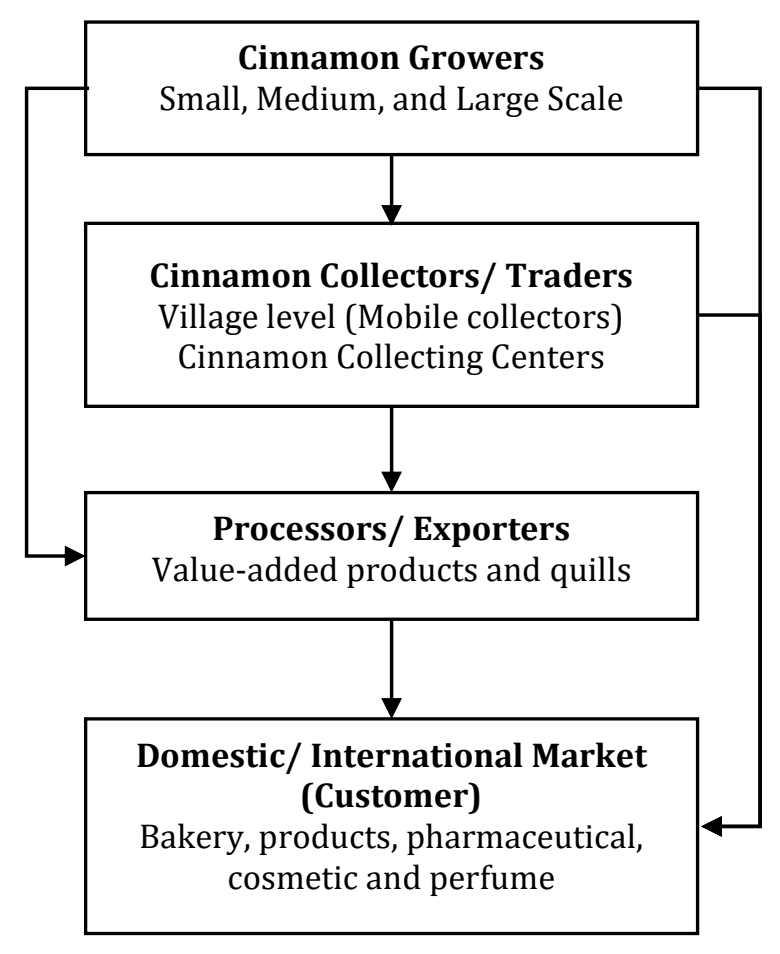

Figure 2. Cinnamon Supply Chain Structure

Growers sold their harvest to collectors at farm gate or the collecting centers near the cultivation area. Growers also directly sold the harvest to the processors or exporters. Growers always sold the harvest for the highest offer since the prices are volatile in the industry. Collectors offer the price based on the quality of the cinnamon. The supply chain issues faced by the collectors are poor hygienic conditions in transport, lack of knowledge for quality standards and high transportation cost (Thibbotuwawa et al. 2017; Yoon et al. 2020).
Processors produced the value-added products and exporters supplied the products to the local and international markets. Exporters mainly collected cinnamon from collectors. Thus, the main barrier they faced is the limited understanding of the cinnamon supply from the collectors due to limited information sharing in the CSC. Ninety percent of the total cinnamon production is exported to Mexico, the USA, Europe and Peru. Noticeably, there is a growing demand for organic cinnamon products in Europe which could be a potential market to reach (Yoon et al. 2020).

\section{Cinnamon Supply Chain risk factor analysis using Standard Risk Matrix}

The Standard Risk Matrix for each risk factor was developed based on the responses collected.

\section{Logistics and Infrastructural Risk}

Table 6 shows the results of the Risk Matrix in logistics and infrastructural risk category. 
Table 6. Risk Matrix Index Results for Logistics and Infrastructural Risk

\begin{tabular}{|l|c|c|c|}
\hline \multirow{2}{*}{ Risk factors } & \multicolumn{3}{|c|}{$\begin{array}{c}\text { Severity as reported by } \\
\text { respondents \% }\end{array}$} \\
\cline { 2 - 4 } & Negligible & Moderate & Critical \\
\hline $\begin{array}{l}\text { Risk of } \\
\text { inventory }\end{array}$ & $3.7 \%$ & $70.4 \%$ & $25.9 \%$ \\
\hline $\begin{array}{l}\text { Risk of } \\
\text { transport }\end{array}$ & $7.5 \%$ & $77.7 \%$ & $14.8 \%$ \\
\hline $\begin{array}{l}\text { Risk of freight } \\
\text { forwarding }\end{array}$ & - & $85.2 \%$ & $14.8 \%$ \\
\hline $\begin{array}{l}\text { Risk of } \\
\text { communication }\end{array}$ & - & $26 \%$ & $74 \%$ \\
\hline
\end{tabular}

\section{Risk of Inventory}

Table 6 depicts $25.9 \%$ of respondents are experiencing the risk of inventory as critical, $70.4 \%$ of respondents are experiencing it as medium and only 3.7\% of respondents are considering it as negligible. Thus, it clearly shows that inventory risk can cause a negative impact to the CSC.

Limited space and utilities are the key issues identified in the inventory. Cinnamon can be stored for a long time. However, depletion of aroma is possible if cinnamon is stored for a period longer than 8 months. No critical threat from pest and diseases had been identified. Poor maintenance of the stores can deteriorate the quality of cinnamon. Moisture level in the stores is critical, where there is a risk of growing fungus due to poor ventilation mechanisms. It was observed that the cinnamon bales were stored in poly sack bags without a proper tracking system for inventories.

The use of computer-aided platforms such as Enterprise Resource Planning (ERP) is minimal in the cinnamon industry. Notably, they relied on paperbased manual process to maintain the inventory. The use of proper inventory rotation techniques such as First-in First-out (FIFO) was not practiced well. Thus, they were not able to share or track the products in real-time to ensure the quality of cinnamon.

\section{Risk of Transport}

Table 6 shows that $14.8 \%$ of respondents experienced risks associated with transport as critical, while $77.7 \%$ reported transport has a moderate risk. Noticeably, only $7.5 \%$ of respondents treated transport risk as negligible. Generally, cinnamon cultivation areas are mostly in Galle, Matara and Ratnapura districts, often collecting centres and collectors are based in the same area. Since all the exporting infrastructures are in place in Colombo, it is mandatory to transport under proper conditions such as proper hygienic and 
moisture conditions, consolidation practices, handling, and packaging, etc.

\section{Risk of Freight Forwarding}

Only $14.8 \%$ reported the risk of freight forwarding is critical, while $85.2 \%$ reported it as moderate (Table 6). Often, exporters use sea freight to ship cinnamon bales and oil to Mexico, USA and Peru, which requires nearly 40-45 days shipment. The major risk is if the shipment gets delayed the quality of cinnamon can be affected. Thus, there is a high possibility to get rejected the whole shipment and returned to the exporter again. Constant communication and real-time visibility may help to overcome such risks.

\section{Risk of Communication}

Table 6 depicts that $74 \%$ of the sampled respondents mentioned that the risk of communication is critical while only $26 \%$ of respondents reported it as moderate. Proper communication was a salient factor in CSC, which is affected by the language differences of export destinations despite language translators are being used. Another barrier is most of the exporters do not maintain digital inventories. Thus, they are unable to maintain the real-time visibility of CSC which ultimately results in poor customer satisfaction.

\section{Market-Related Risk}

Table 7 shows the results of the Risk Matrix in market related risk category.

Table 7. Risk Matrix Index Results for Market Related Risk

\begin{tabular}{|l|c|c|c|}
\hline \multirow{2}{*}{ Risk factors } & \multicolumn{3}{|c|}{$\begin{array}{c}\text { Severity as reported by } \\
\text { respondents \% }\end{array}$} \\
\cline { 2 - 4 } & Negligible & Moderate & Critical \\
\hline $\begin{array}{l}\text { Changes } \\
\text { related to } \\
\text { the market } \\
\text { and demand }\end{array}$ & - & $88.8 \%$ & $11.2 \%$ \\
\hline $\begin{array}{l}\text { Impact of } \\
\text { domestic } \\
\text { and } \\
\text { international } \\
\text { prices }\end{array}$ & $7.5 \%$ & $92.5 \%$ & - \\
\hline $\begin{array}{l}\text { Timing of } \\
\text { product } \\
\text { delivery }\end{array}$ & - & $26 \%$ & $74 \%$ \\
\hline
\end{tabular}

Changes related to the Market and Demand

Table 7 depicts that $11 \%$ of the respondents experienced risk related to market and demand as critical, while $88.8 \%$ of respondents identified it as moderate.

There is a product called "Cassia" form China which has a similar physical appearance to Sri Lankan cinnamon. Thus, it is difficult to distinguish one from the other. The key issue is, it is a 
low-quality and a low priced product compared to Sri Lankan cinnamon.

Furthermore, a lack of market research also identified as a salient issue since there is no proper mechanism to identify the market changes. Thus, it is difficult to identify the market trends and pattern Hence, exporters rely on the upstream of the CSC to cater to the market changes.

\section{Impact of Domestic and International} Prices

Interestingly, none of the respondents says the impact of domestic and international prices as a critical risk (Table 7). The majority (92.5\%) of respondents identified that it as a moderate risk while $7.5 \%$ of respondents said the risk is negligible. Seasonality and the weather patterns are the key drivers of the pricing in the domestic market. However, prices can be varied based on the quality of the cinnamon. However, international market prices remain more stable, despite fluctuations of exchange rate affects the risk.

\section{Timing of Product Delivery}

Table 7 shows that $74 \%$ of respondents experienced the risk of the timing of product delivery as critical, while $26 \%$ of respondents identified it as a moderate risk. Delays in deliveries can servilely affect the quality of the cinnamon products; therefore, respondents considered this as critical Customers tend to reduce the total payment by $5 \%$ if shipment delays or returns due to poor quality.

\section{Management and Operational Risk}

Table 8 shows the results of the Risk Matrix in management and operational risk category.

Table 8. Risk Matrix Index Results for Management and Operational Risk

\begin{tabular}{|l|c|c|c|}
\hline \multirow{2}{*}{ Risk factors } & \multicolumn{4}{|c|}{$\begin{array}{c}\text { Severity as reported by } \\
\text { respondents \% }\end{array}$} \\
\cline { 2 - 4 } & Negligible & Moderate & Critical \\
\hline $\begin{array}{l}\text { Management } \\
\text { decision } \\
\text { making }\end{array}$ & $66 \%$ & $44 \%$ & - \\
\hline $\begin{array}{l}\text { Quality } \\
\text { control }\end{array}$ & - & $18.6 \%$ & $81.4 \%$ \\
\hline $\begin{array}{l}\text { Changes in } \\
\text { labour force }\end{array}$ & - & $89 \%$ & $11 \%$ \\
\hline $\begin{array}{l}\text { Lack of } \\
\text { technology }\end{array}$ & - & $66.7 \%$ & $33.3 \%$ \\
\hline
\end{tabular}


Management Decision Making

Only $44 \%$ of the respondents experienced risks related to management decision making as moderate (Table 8). Rest (66\%) of the respondents identified the risk as negligible. Most of the companies in the cinnamon industry are family-owned, hence satisfied with the management. However, they still follow the traditional methods and processes which may hinder their competitive edge in the global market.

\section{Quality Control}

Table 8 shows majority (81.4\%) of the respondents agree on that the risks related to quality control are critical while the rest of the $18.6 \%$ said it is moderate. Deterioration of appearance and aroma reduce the quality of cinnamon. Furthermore, the prices depend on the quality of the cinnamon. Especially, exporters pay their attention to the quality control in shipments because products may reject due to poor quality. Thus, the exporters based in rural areas have to make an extra effort (e.g., logistics arrangements) to obtain required quality certifications because certification agencies are located far away in Colombo. Further, this limits their ability to get assistance related to quality control practices when needed.

\section{Changes in labour Force}

Table 8 depicts that only 11\% of the respondents identified the risks of changes in the labour force as critical while the majority (89\%) identified as moderate. The cinnamon industry is a labor-intensive industry. It also requires skilled labour for peeling. One of the critical risks that the industry faces is the lack of skilled labour. Cinnamon industry is less attractive to younger generation due to lack of recognition. Furthermore, most of the labour force is not aware of the global standards and the practices. Therefore, finding the competent labor is becoming a challenge.

\section{Lack of Technology}

Table 8 depicts that $33.3 \%$ of respondents experienced critical risks arise from limited technology. while the rest $(66.7 \%)$ perceived it was moderate. Poor information sharing, timeconsuming manual work, laborintensive working practices, limited 
access to international markets have resulted due to poor use of technology.

\section{Public Policy and Institutional Risk}

Table 9 shows the results of the Risk Matrix in public policy and institutional risk category.

Table 9. Risk Matrix Results for Public Policy and Institutional Risk

\begin{tabular}{|l|c|c|c|}
\hline \multirow{2}{*}{$\begin{array}{l}\text { Risk } \\
\text { factors }\end{array}$} & \multicolumn{3}{|c|}{$\begin{array}{c}\text { Severity as reported by } \\
\text { respondents \% }\end{array}$} \\
\cline { 2 - 4 } & Negligible & Moderate & Critical \\
\hline $\begin{array}{l}\text { Financial } \\
\text { and tax } \\
\text { policies }\end{array}$ & $40.8 \%$ & $59.2 \%$ & - \\
\hline $\begin{array}{l}\text { Regulatory } \\
\text { and legal } \\
\text { policies }\end{array}$ & - & $81.9 \%$ & $18.1 \%$ \\
\hline $\begin{array}{l}\text { Trade \& } \\
\text { market } \\
\text { policies }\end{array}$ & $37.1 \%$ & $62.9 \%$ & - \\
\hline $\begin{array}{l}\text { Weak } \\
\text { institutional } \\
\text { capacity }\end{array}$ & $78 \%$ & $22 \%$ & - \\
\hline
\end{tabular}

\section{Financial and Tax Policies}

Table 9 depicts that none of the respondents experiences the risks related to financial and tax policies as critical. $59.2 \%$ of the respondents say it is a moderate risk while the rest of the $40.8 \%$ of respondents say the risk can be negligible. There are no strict tax policies related to cinnamon exports. However, if exporters export cinnamon products to a country which has trade sanctions, there are risks of financial and geopolitics.

\section{Regulatory and Legal Policies}

Only $18.1 \%$ of the respondents say the risks related to regulatory and legal policies as critical while the rest of the $81.9 \%$ of respondents says it as moderate (Table 9). None of the respondents agrees on the risk as negligible. Export market of the cinnamon involves a lot of legal procedures. First, the exporter needs to register with Sri Lanka Export Development Board (SLEDB), Inland Revenue Department and Sri Lanka Customs. The register number is given from the Export Development Board and the tax identification number (TIN/ VAT number) is given by the Inland Revenue Department. After the registration, the exporter needs to get the license to use Pure Ceylon Cinnamon logo from Sri Lanka Export Development Board and inspection certificates from Sri Lanka Standard Institution (SLSI) or SGS Lanka (Pvt) Ltd.

The exporter and importer sign a sales contract to ensure the legal protection for both the parties which includes 
product details, names of the buyer and seller, information regarding the cost and delivery, terms and conditions of sale. Furthermore, the exporter needs to send the Performa Invoice to the buyer which includes product description, quantity, price, terms of payments (L/C, $\mathrm{D} / \mathrm{P}, \mathrm{D} / \mathrm{A}$, etc.), terms of delivery (CIF, FOB, Ex-works, etc.) and packing details. The exporter also prepares the commercial invoice which shows the Customs Authority of importing country and selling price and other specific costs for freight, insurance and packing, terms of delivery and payment should be mentioned. The weight and dimensions, number of packages are included in the packing list.

Certificate of Origin (GSP certificate) is required by the Customs Authority of the importing country for the buyer to obtain the duty concessions under GSP. The statement is signed by the exporter and attested by Department of Commerce mentioning that the product being shipped was originated in Sri Lanka. Certificate of Origin also is required by the Customs Authority of importing country and is issued by Chamber of Commerce (Ceylon Chamber of Commerce, National Chamber of Commerce). Fumigation certificate also is required by the buyer to import agricultural products. The cinnamon leaf oil and bark oil are treated as dangerous cargos (DG cargo) and it is essential to submit Material Safety Data Sheets (MSDS) along with the shipments. In Customs Goods Declaration (CUSDEC), the details of the product being imported or exported are provided and it is declared to the relevant authorities in international trade. The CUSDEC needs to be filled carefully as it is vital to declare the statistical implications and revenue details.

\section{Trade \& Market Policies}

Table 9 shows that none of the respondents identifies the risks related to trade and market policies as critical. $62.9 \%$ of the respondents say the risk is moderate while $37.1 \%$ of respondents say the risks can be negligible. There are mutual trade agreements between countries to overcome the risks related to trade and market policies. Such one of the agreements is SAPTA, the agreement on SAARC preferential Trading Agreement is applicable for the seven- 
member countries of South Asia, to liberalize the trade among the SAARC countries. It promotes mutual trade and economy among the member countries. It also negotiates the tariff reduction, in the trade. Again, there is Indo Sri Lanka Free Trade Agreement (ISFTA) which provides duty-free concessions to the products including cinnamon traded between two countries.

\section{Weak Institutional Capacity}

Notably, none of the respondents experienced risks of weak institutional capacity as critical. Only $22 \%$ of respondents see the risks as moderate. However, majority of the respondents, $78 \%$ says the risks related to weak institutional capacity are negligible. Furthermore, Government institutions make efforts to promote Ceylon Cinnamon brand name in Global market. However, most of the local events are not well connected with the global markets. Thus, the cinnamon exporters are facing difficulties to create access to new markets. One of the ways to create new markets is to participate in the species exhibitions such as Gulfood, IFEAT and Global spices.

\section{Political Risk}

Table 10 shows the results of the Risk Matrix in political risk category.

Table 10. Risk Matrix Index Results for Political Risk

\begin{tabular}{|l|c|c|c|}
\hline \multirow{2}{*}{ Risk factors } & \multicolumn{3}{|c|}{$\begin{array}{c}\text { Severity as reported by } \\
\text { respondents \% }\end{array}$} \\
\cline { 2 - 4 } & Negligible & Moderate & Critical \\
\hline $\begin{array}{l}\text { Political } \\
\text { environment } \\
\text { of the } \\
\text { country }\end{array}$ & $51.9 \%$ & $48.1 \%$ & - \\
\hline $\begin{array}{l}\text { Interruption } \\
\text { of trade due } \\
\text { to dispute }\end{array}$ & - & $14.9 \%$ & $29.6 \%$ \\
\hline
\end{tabular}

\section{Political Environment of the Country}

Table 10 shows that none of the respondents says risks related to the political environment of the country as critical. However, $48.1 \%$ experiences it as a moderate risk while $51.9 \%$ says the risk can be negligible. One of the reasons for the favorable political environment is the initiatives for proper policy formation in recent past such as tax exemptions (e.g., VAT, NBT, 14\% from the income tax).

\section{Interruption of Trade due to Dispute}

Table 10 shows that $29.6 \%$ of respondents said that the risks related to the interruption of trade due to dispute 
are critical while $55.5 \%$ of respondents say the risks are moderate. However, $14.9 \%$ of respondents says the risks can be negligible. Though Ceylon Cinnamon has a good reputation in the global market, we are bounded to adhere decisions and trade policies imposed by World organizations such as United Nation (UN) and World Trade Organization (WTO). Furthermore, even these trade decisions such as sanctions can be imposed by a powerful country over another country. In such situations also, we might have to avoid doing trading with such countries due to geopolitical reasons. One of the recent incidents is the trade sanctions imposed by the UN over Iran. Thus, we lost our Iranian cinnamon market.

\section{Risk Related to Nature}

Table 11 shows the results of the Risk Matrix in environmental risk category.

Table 11. Risk Matrix Index Results for Risk Related to Nature

\begin{tabular}{|l|c|c|c|}
\hline \multirow{2}{*}{ Risk factors } & \multicolumn{3}{|c|}{$\begin{array}{c}\text { Severity as reported by } \\
\text { respondents \% }\end{array}$} \\
\cline { 2 - 4 } & Negligible & Moderate & Critical \\
\hline $\begin{array}{l}\text { Natural } \\
\text { disasters }\end{array}$ & - & $85.2 \%$ & $14.8 \%$ \\
\hline $\begin{array}{l}\text { Biological and } \\
\text { environmental } \\
\text { risk }\end{array}$ & $14.4 \%$ & 85.1 & $0.5 \%$ \\
\hline
\end{tabular}

\section{Natural Disasters}

Table 11 shows that $14.8 \%$ of respondents experience the risks related to natural disasters as critical while the majority, $85.2 \%$ of respondents says the risks as moderate. However, none of the respondents says the risks can be negligible. Cinnamon being an agricultural product, it is more sensitive to natural disasters related to weather patterns changes. Furthermore, during the raining seasons, there is a high risk of fungus growing in the storages due to humidity.

\section{Biological and Environmental Risk}

Only $0.5 \%$ of the respondents see the risks related to biological and environmental as critical. The majority, $85.1 \%$ of respondents sees the risks as moderate while $14.4 \%$ of respondents says the risks can be negligible (Table 11). Though there are no high biological risks in cinnamon cultivation, environmental risks can make a huge impact on the quality of cinnamon. Cinnamon needs to store in a proper environment with a good ventilation system to overcome the risk of fungus. Furthermore, the hygienic conditions 
also need to be in place to avoid the dusty environment to ensure the quality of cinnamon. On the other hand, there is a growing market demand for organic cinnamon. Thus, the challenge is to cultivate cinnamon in a chemical-free environment.

\section{Critical Supply Chain Risks in Cinnamon Export Industry}

Table 12 depicts the mean values of the CSC risks.

Table 12. Mean Value for the Supply Chain Risk factors

\begin{tabular}{|c|c|c|c|c|c|}
\hline & Risk Factor & $\begin{array}{c}\text { Risk } \\
\text { Id }\end{array}$ & $\begin{array}{l}\text { Mean Value of } \\
\text { Probability }\end{array}$ & $\begin{array}{l}\text { Mean Value of } \\
\text { Severity }\end{array}$ & $\begin{array}{l}\text { Mean Value } \\
\text { for Risk }\end{array}$ \\
\hline & istical and infrastructural risk & & & & \\
\hline 1) & Risk of inventory & A & 3.18 & 3.66 & 11.64 \\
\hline 2) & Risk of transport & $\mathrm{B}$ & 2.70 & 3.22 & 8.69 \\
\hline 3) & Risk of freight forwarding & $\mathrm{C}$ & 2.96 & 3.74 & 11.07 \\
\hline 4) & Communication risk & $\mathrm{D}$ & 3.37 & 4.55 & 15.33 \\
\hline & ket-related risk & & & & \\
\hline 1) & $\begin{array}{l}\text { Changes related to the market \& } \\
\text { demand }\end{array}$ & $\mathrm{E}$ & 2.96 & 3.66 & 10.83 \\
\hline 2) & $\begin{array}{l}\text { Impact of domestic \& international } \\
\text { prices }\end{array}$ & $\mathrm{F}$ & 2.77 & 3.03 & 8.39 \\
\hline 3) & Timing of product delivery & G & 3.33 & 4.51 & 15.02 \\
\hline & hagement \& operational risk & & & & \\
\hline 1) & Management decision making & $\mathrm{H}$ & 2.00 & 2.37 & 4.74 \\
\hline 2) & Quality control & I & 3.96 & 4.62 & 18.30 \\
\hline 3) & Changes in labor force & $\mathrm{J}$ & 2.96 & 3.40 & 10.06 \\
\hline 4) & Lack of technology & K & 3.14 & 4.07 & 12.82 \\
\hline & lic policy and institutional risk & & & & \\
\hline 1) & Financial and tax policies & $\mathrm{L}$ & 2.33 & 2.44 & 5.69 \\
\hline 2) & Regulatory and legal policies & $\mathrm{M}$ & 2.48 & 3.96 & 9.82 \\
\hline 3) & Trade \& market policies & $\mathrm{N}$ & 2.37 & 2.51 & 5.95 \\
\hline 4) & Weak institutional capacity & 0 & 1.74 & 2.33 & 4.05 \\
\hline & ntification of political risk & & & & \\
\hline 1) & Political environment of the country & $\mathrm{P}$ & 2.00 & 2.37 & 4.74 \\
\hline 2) & Interruption of trade due to dispute & Q & 2.96 & 3.33 & 9.86 \\
\hline & $\mathrm{k}$ related to nature & & & & \\
\hline 1) & Natural disasters & $\mathrm{R}$ & 2.70 & 3.59 & 9.69 \\
\hline 2) & Biological \& environmental risk & $S$ & 2.66 & 3.14 & 8.35 \\
\hline
\end{tabular}




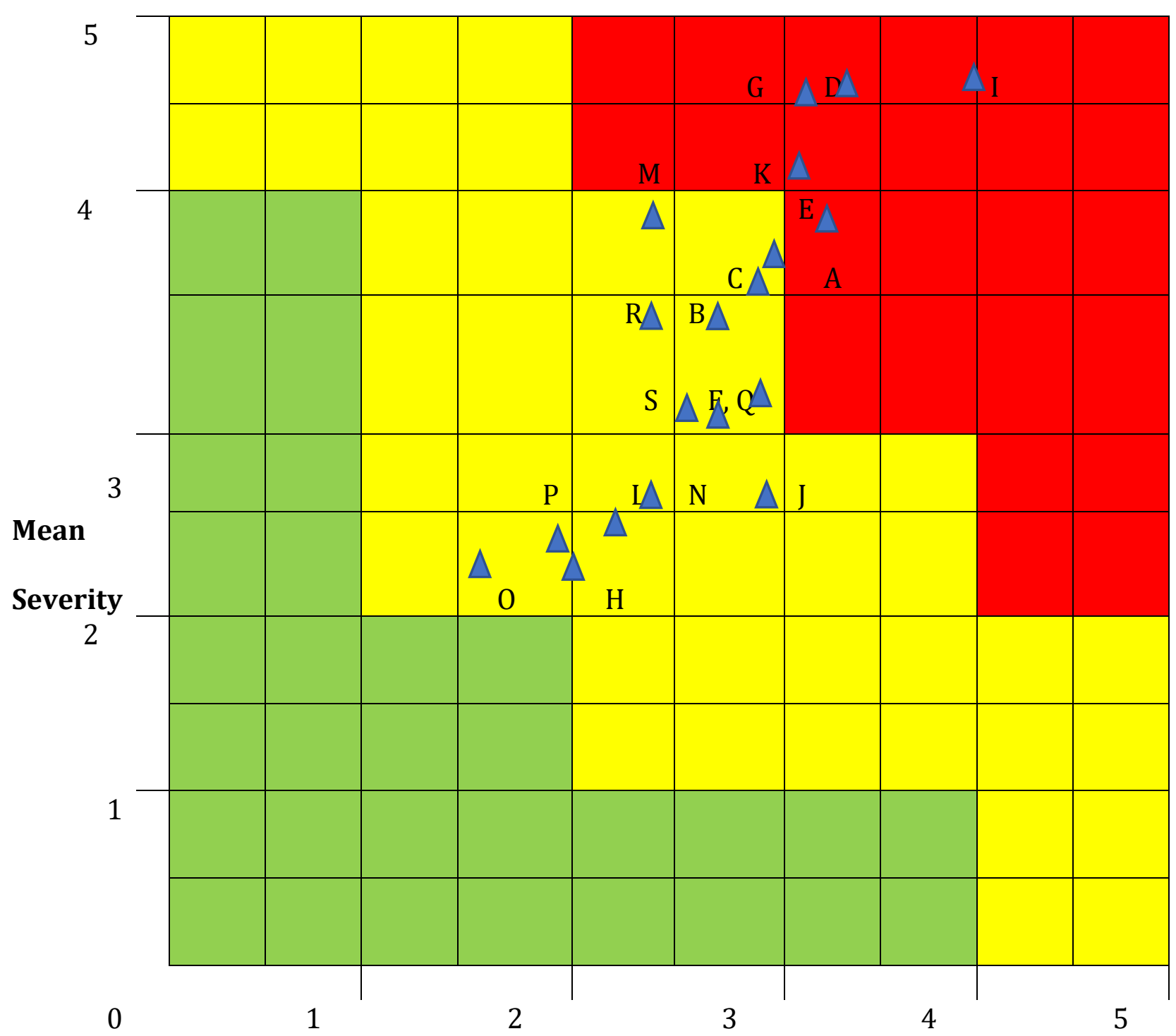

Mean Probability

Figure 3. Supply Chain Risk Grid Matrix for Cinnamon Export Industry

Risk Grid Matrix clearly shows that there are five factors in the Critical level

(Fig. 3); (1) Quality Control, (2)

Communication Risk, (3) Timing of

Product Delivery,
(4) Risk of Inventory and (5) Lack of Technology. The risk mitigation strategies were developed based on the identified critical risk factors. 
Risk Mitigation Strategies for Major

Risk factors in Cinnamon Export Industry

\section{Quality Control}

- Achieve product excellence through research and innovation partnering with institutions (educational, research) to develop cinnamon industry.

- Encourage Government initiatives on promoting the awareness and knowledge on best practices through workshops among the stakeholders in CSC.

- Establish regional level quality inspection institutions to provide quick and convenient services to the cinnamon exporters.

- Initiate technological enhancements to ensure the quality of cinnamon; for example, to control humidity within the warehouses, encourage using dehumidifier controlling units.

- Improve the well-recognized quality standards through strategic initiatives and encourage the industry to use them by providing certifications.

\section{Communication Risk}

- Initiatives on improving the language skills of the exporting personnel and provide them continuous support through language professionals.

- Ensure accurate, reliable, and timely information along with the CSC for strategic decision making by initiating a community platform to digitize the CSC eco-system.

- Introduce well-developed training programs through Vocational Training Centers.

\section{Timing of Product Delivery}

- Encourage to use automated systems instead of the manual processes for CSC to run the processes smoothly.

- Maintain one centralized platform to enhance the visibility of the CSC and share information with respective supply chain actors to take timely decisions.

- Provide training on documentation (e.g., invoice, packing lists, inspection reports, Bill of Lading, inspection reports, Country of Origin certificates, fumigation certificates, etc.) to avoid documentation errors. 


\section{Risk of Inventory}

- Encourage to use ventilation systems or humidity control systems to the warehouses where the cinnamon products are stored.

- Create awareness on maintaining hygiene conditions during processing, collection and storing cinnamon products in the warehouses engaging with industry leaders.

- Encourage investments on modern state-of-the-art Warehouse Manage ment System (WMS) to enable realtime information availability.

- Create awareness on the best practices for storing, handling, picking, and packing methods through workshops.

- Encourage the new investments on warehouse infrastructures (e.g., racking systems) and provide Government support where necessary (e.g., financial support).

\section{Lack of Technology}

- Encourage public and private partnerships on new technological investments.
- Encourage innovations for cinnamon industry and provide Government support where necessary.

- Initiate common user platforms in cinnamon industry to enable technological accessibility for every stakeholder such as community platform, e-marketplace, Transport Management System (TMS), etc.

- Implement a workflow management system to provide e-approval for export documents by providing onestop-shop eco-system.

\section{Conclusions}

Main objectives of our study were to recognize the risk factors in cinnamon export industry and to provide mitigation strategies to overcome the adverse effects of those risk factors.

We have identified 5 critical risk factors through factor analysis which require immediate action to mitigate; (1) Quality control, (2) communication risk, (3) timing of product delivery, (4) risk of inventory and (5) lack of technology. Similar findings have been explained by Hirimuthugodage (2016), Thanthirige (2011), Thibbotuwawa et al. (2017) and Yoon et al. (2020). 
The key areas we should look into as mitigation strategies are technological enhancements, research and development and Government initiatives to make awareness on industry best practices. Even though the findings of our research are robust, our study has some limitations. Our target group of the research was exporters. Thus, we did not thoroughly explore the supply chain issues faced by producers and collectors. We were able to collect responses from 27 respondents only for this study due to time constraints. Risk Matrix was used as the key technique in this research. Thus, analyzing the risk factors in CSC industry using more advanced techniques such as principal components analysis (PCA), MICMAC analysis could be a future research avenue in this arena.

Conflicts of interest: The authors have no conflicts of interest regarding this publication.

\section{References}

Balachandra, K., Perera, H. N. and Thibbotuwawa, A. (2020) 'Human Factor in Forecasting and Behavioral Inventory Decisions: A System Dynamics
Perspective BT - Dynamics in Logistics', in Freitag, M. et al. (eds). Cham: Springer International Publishing, pp. 516-526.

Bawappa, K. V. A. et al. (2005) Technical Bulletin No 5: Cinnamon Plantation and Preparation.

DEA (2014) Annual Performance Report, Department of Export Agriculture Ministry of Minor Export Crop Promotion.

DEA (2017) Annual Performance Report.

EDB (2018) Annual Report 2018, SRI LANKA EXPORT DEVELOPMENT BOARD.

Hettiarachchi, I. C. et al. (2020) 'An assessment of market landscape of cinnamon in Sri Lanka', Journal of Agricultural Sciences - Sri Lanka, 15(2), pp. 207-221. doi: 10.4038/jas .$v 15 i 2.8801$.

Hirimuthugodage, D. (2016) Analyzing Quality Constraints in Sri Lankan Cinnamon Value Chain.

Ho, W. et al. (2015) 'Supply chain risk management: A literature review', International Journal of Production Research, 53(16), pp. 5031-5069. doi: 10.1080/00207543.2015.1030467. 
Perera, N., Behnam, F. and Travis, T. (2020) 'Inventory and ordering decisions: a systematic review on research driven through behavioral experiments', International Journal of Operations \& Production Management. doi: 10.1108/IJOPM-05-2019-0339.

Perera, S., Perera, H. N. and Kasthurirathna, D. (2017) 'Value chain approach for modelling resilience of tiered supply chain networks', 3rd International Moratuwa Engineering Research Conference, MERCon 2017, pp. 159-164. doi: 10.1109/MERCon. 2017.7980474 .

Qazi, A. and Akhtar, P. (2020) 'Risk matrix driven supply chain risk management: Adapting risk matrix based tools to modelling interdependent risks and risk appetite', Computers and Industrial Engineering, 139. doi: 10.1016/j.cie.2018.08.002.

Ratnayake, R. M. C. and Antosz, K. (2017) 'Development of a Risk Matrix and Extending the Risk-based Maintenance Analysis with Fuzzy Logic', Procedia Engineering, 182(1877), pp. 602-610. doi: 10.1016/j.proeng.2017.03.163.
Silva, S. D. (2014) 'Major challenges confront Sri Lanka's spice exporters', Sunday Times.

Sugathadasa, P. and Rajapaksha, S. (2011) 'An investigation on relationship between third party logistics user and provider at FMCG industry in Sri Lanka', in 17th Annual Research Symposium on Excellence in Research, Excelling a Nation. Faculty of Engineering, University of Moratuwa. Available at: http://dl.lib.mrt. ac.lk/handle/123/8045.

Sugathadasa, P. T. R. et al. (2021) 'Analysis of Risk Factors for Temperature- Controlled Warehouses', 14(3), pp. 320-337.

Sugathadasa, P. T. R. S., Perera, H. N. and Liyanage, A. K. (2020) 'Effective Management of Manufacturing Supply Chain Risks: A Sri Lankan Perspective', Engineer: Journal of the Institution of Engineers, Sri Lanka, 53(3), p. 63. doi: 10.4038/engineer.v53i3.7421.

Sugathadasa, R. et al. (2021) 'Motivation Factors of Engineers in Private Sector Construction Industry', Journal of Applied Engineering Science, pp. 1-12. doi: 10.5937/jaes0-29201. 
Thanthirige, J. B. (2011) 'Technology and Marketing Issues in Cinnamon Industry in Sri Lanka', (December). Available at: http://dl.lib.mrt.ac.lk/bitstream/handle /123/9972/pre-text.pdf?sequence=1.

Thibbotuwawa, M., Wijayasiri, J., Hirimuthugodage, D. (2017) 'Analysis of cinnamon, peper and cardamom value chains in Sri Lanka', (December 2018), p. 93. Available at: https://www.research gate.net/publication/329800013_ANAL YSIS_OF_CINNAMON_PEPPER_AND_CAR DAMOM_VALUE_CHAINS_IN_SRI_LANK A/Stats.

UNIDO (2016a) Enhancing capacity in the cinnamon value chain. Available at: https://www.standardsfacility.org/PG343\#: :text=The project's key object ives were ,requirements of high-end markets.
UNIDO (2016b) SRI LANKA ' $S$ CINNAMON EXPORTS GET $A$ COMPETITIVE EDGE IN GLOBAL MARKETS. Available at: https://www.sta ndardsfacility.org/PG-343.

Yoon, J., Jang, H. and Cho, S. (2020) Get to Know the Market with Tridge Analysis on the Cinnamon Industry in Sri Lanka Acknowledgments. 
Annexure: Research Questionnaire

Identifying the Supply Chain Risk Factors in Cinnomon Export Industry

Conducted By:S.P.A.V.S.Samarakoon

Department of Transport And Logistics Management

\section{Section A}

Information about the Organization

1.) Name of the company

2.) Number of employees
$\bigcirc<100$
$100-200$
$200-300$
○ $300<$

3.) Average Annual Export Turnover (\$ million)

$\bigcirc<5$

○ $5-10$

$10-12$

$12<$

\section{4.) Export Market Region}

$\bigcirc$ U.S.A/ South American Countries

Europe

Middle East

Other 


\section{Section B}

\section{Selecet the suitable option}

Probability Options:

V.L-Very Low (0.00-0.10 ) L-Low (0.10-0.40) M-Moderate (0.40-0.60 ) H-High (0.60-0.90)

V.H-Very High (0.90-1.00)

Severity Options:

V.L-Very Low L-Low M-Moderate H-High V.H-Very High

\section{Identification of Logistical and Infastructural risk}

\begin{tabular}{|c|c|c|c|c|c|c|c|c|c|c|}
\hline \multirow[b]{2}{*}{ Risk Factor } & \multicolumn{5}{|c|}{ Probability } & \multicolumn{5}{|c|}{ Severity (Impact) } \\
\hline & V.L & $\mathrm{L}$ & $\mathrm{M}$ & $\mathrm{H}$ & V.H & V.L & $\mathrm{L}$ & $\mathrm{M}$ & $\mathrm{H}$ & V.H \\
\hline Risk of Inventory & 1 & 2 & 3 & 4 & 5 & 1 & 2 & 3 & 4 & 5 \\
\hline Risk of Transport & 1 & 2 & 3 & 4 & 5 & 1 & 2 & 3 & 4 & 5 \\
\hline $\begin{array}{l}\text { Risk of Freight } \\
\text { Forwarding }\end{array}$ & 1 & 2 & 3 & 4 & 5 & 1 & 2 & 3 & 4 & 5 \\
\hline Communication Risk & 1 & 2 & 3 & 4 & 5 & 1 & 2 & 3 & 4 & 5 \\
\hline
\end{tabular}


Identification of risk related to the Market

\begin{tabular}{|c|c|c|c|c|c|c|c|c|c|c|}
\hline \multirow[b]{2}{*}{ Risk Factor } & \multicolumn{5}{|c|}{ Probability } & \multicolumn{5}{|c|}{ Severity (Impact) } \\
\hline & V.L & $\mathrm{L}$ & $\mathrm{M}$ & $\mathrm{H}$ & V.H & V.L & $\mathrm{L}$ & $\mathrm{M}$ & $\mathrm{H}$ & V.H \\
\hline $\begin{array}{l}\text { Changes related to the } \\
\text { market and demand }\end{array}$ & 1 & 2 & 3 & 4 & 5 & 1 & 2 & 3 & 4 & 5 \\
\hline $\begin{array}{l}\text { Impact of domestic and } \\
\text { international prices }\end{array}$ & 1 & 2 & 3 & 4 & 5 & 1 & 2 & 3 & 4 & 5 \\
\hline $\begin{array}{l}\text { Timing of product } \\
\text { Delivery }\end{array}$ & 1 & 2 & 3 & 4 & 5 & 1 & 2 & 3 & 4 & 5 \\
\hline
\end{tabular}

Identification of Management and Operational risk

\begin{tabular}{|c|c|c|c|c|c|c|c|c|c|c|}
\hline \multirow[b]{2}{*}{ Risk Factor } & \multicolumn{5}{|c|}{ Probability } & \multicolumn{5}{|c|}{ Severity (Impact) } \\
\hline & V.L & $\mathrm{L}$ & $\mathrm{M}$ & $\mathrm{H}$ & V.H & V.L & $\mathrm{L}$ & $\mathrm{M}$ & $\mathrm{H}$ & V.H \\
\hline $\begin{array}{l}\text { Management Decision } \\
\text { Making }\end{array}$ & 1 & 2 & 3 & 4 & 5 & 1 & 2 & 3 & 4 & 5 \\
\hline Quality Control & 1 & 2 & 3 & 4 & 5 & 1 & 2 & 3 & 4 & 5 \\
\hline Changes in Labor Force & 1 & 2 & 3 & 4 & 5 & 1 & 2 & 3 & 4 & 5 \\
\hline Lack of Technology & 1 & 2 & 3 & 4 & 5 & 1 & 2 & 3 & 4 & 5 \\
\hline
\end{tabular}


Identification of Public Policy and institutional risk

\begin{tabular}{|c|c|c|c|c|c|c|c|c|c|c|}
\hline \multirow[b]{2}{*}{ Risk Factor } & \multicolumn{5}{|c|}{ Probability } & \multicolumn{5}{|c|}{ Severity (Impact) } \\
\hline & V.L & $\mathrm{L}$ & $\mathrm{M}$ & $\mathrm{H}$ & V.H & V.L & $\mathrm{L}$ & $\mathrm{M}$ & $\mathrm{H}$ & V.H \\
\hline Financial and Tax policies & 1 & 2 & 3 & 4 & 5 & 1 & 2 & 3 & 4 & 5 \\
\hline Regulatory an legal policies & 1 & 2 & 3 & 4 & 5 & 1 & 2 & 3 & 4 & 5 \\
\hline Trade and market poicies & 1 & 2 & 3 & 4 & 5 & 1 & 2 & 3 & 4 & 5 \\
\hline Weak Institutional Capacity & 1 & 2 & 3 & 4 & 5 & 1 & 2 & 3 & 4 & 5 \\
\hline
\end{tabular}

\section{Identification of Political risk}

\begin{tabular}{|l|l|l|l|l|l|l|l|l|l|l|l|l|l|l|l|}
\hline \multirow{2}{*}{ Risk Factor } & \multicolumn{3}{|c|}{ Probability } & \multicolumn{7}{|c|}{ Severity (Impact) } \\
\cline { 2 - 13 } & V.L & L & M & H & V.H & V.L & L & M & H & V.H \\
\hline $\begin{array}{l}\text { Political instability within the } \\
\text { country }\end{array}$ & 1 & 2 & 3 & 4 & 5 & 1 & 2 & 3 & 4 & 5 \\
\hline $\begin{array}{l}\text { Interruption of trade due to } \\
\text { disputes }\end{array}$ & 1 & 2 & 3 & 4 & 5 & 1 & 2 & 3 & 4 & 5 \\
\hline
\end{tabular}

\section{Identification of risk related to nature}

\begin{tabular}{|l|l|l|l|l|l|l|l|l|l|l|}
\hline \multirow{2}{*}{ Risk Factor } & \multicolumn{5}{|c|}{ Probability } & \multicolumn{5}{c|}{ Severity impact } \\
\cline { 2 - 11 } & V.L & L & M & H & V.H & V.L & L & M & H & V.H \\
\hline Natural disasters & 1 & 2 & 3 & 4 & 5 & 1 & 2 & 3 & 4 & 5 \\
\hline $\begin{array}{l}\text { Biological and } \\
\text { Enviromental risk }\end{array}$ & 1 & 2 & 3 & 4 & 5 & 1 & 2 & 3 & 4 & 5 \\
\hline
\end{tabular}

